Available online at: $h$ ttp://journal.uny.ac.id/index.php/litp
LingTera, 5 (2), 2018, 120-132

\title{
Tindak tutur direktif dalam buku ajar bahasa Prancis Écho 1 dan sumbangannya dalam pembelajaran bahasa Prancis
}

\author{
Desi Rahmawati *, Dwiyanto Djoko Pranowo \\ Program Studi Linguistik Terapan, Program Pascasarjana, Universitas Negeri Yogyakarta \\ Jalan Colombo No. 1, Yogyakarta, 55281, Indonesia \\ * Corresponding Author. Email: desirahmawati.dira@gmail.com \\ Received: 12 October 2016; Revision: 6 August 2018; Accepted: 31 December 2018
}

\begin{abstract}
Abstrak
Penelitian ini bertujuan untuk mendeskripsikan (1) bentuk dan jenis tindak tutur direktif yang terdapat dalam buku ajar bahasa Prancis Écho 1, (2) sumbangan hasil kajian tindak tutur direktif yang terdapat dalam buku ajar bahasa Prancis Écho 1 terhadap pembelajaran bahasa Prancis. Teknik pengumpulan data menggunakan metode simak dengan teknik dasar teknik sadap, dilanjutkan dengan teknik SBLC (Simak Bebas Libat Cakap) dan teknik catat. Data bentuk tindak tutur direktif dianalisis menggunakan metode agih. Untuk menganalisis jenis tindak tutur direktif digunakan metode padan pragmatis. Hasil penelitian menunjukkan bahwa: (1) bentuk tindak tutur direktif yang terdapat dalam buku ajar bahasa Prancis Écho 1 yakni bentuk tindak tutur direktif langsung dan tindak tutur direktif tidak langsung, (2) jenis tindak tutur direktif yang terdapat dalam buku ajar bahasa Prancis Écho 1 antara lain requestive, question, requirement, prohibitive, permissive, dan advisory, (3) sumbangan hasil kajian tindak tutur direktif yang terdapat dalam buku ajar bahasa Prancis Écho 1 terhadap pembelajaran bahasa yakni penggunaan strategi pembelajaran model 6R yang terdiri dari researching, reflecting, receiving, reasoning, rehearsing, dan revising.
\end{abstract}

Kata Kunci: tindak tutur direktif, bentuk tindak tutur direktif, jenis tindak tutur direktif, sumbangan hasil kajian tindak tutur direktif

\section{Directive speech act in French textbook Écho 1 and its contribution in French language learning}

\begin{abstract}
This study aims to describe (1) the forms and types of directive speech act in French textbook entitled Écho 1, and (2) the contribution of the study about directive speech in the textbook for learning French. This study refers to qualitative study. The data were gathered through observation, as the basic technique was tapping technique. Then it was followed by Uninvolved Conversation Observation Technique and combined with record technique. To analyze the forms and the types of directive speech act, the researcher used distributional and identity method respectively. The results of the study show that (1) the forms of directive speech act found in the textbook are direct speech act and indirerct speech act, (2) the types of directive speech act found in the textbook are requestive, question, requirement, prohibitive, permissive, and advisory, (3) the contribution of the study regarding directive speech act in the textbook is the use of $6 R$ strategy in learning French consisting of researching, reflecting, receiving, reasoning, rehearsing, and revising.
\end{abstract}

Keywords: directive speech act, form of directive speech act, type of directive speech act, contribution of the study regarding directive speech act

How to Cite: Rahmawati, D., \& Pranowo, D. (2018). Tindak tutur direktif dalam buku ajar bahasa Prancis Écho 1 dan sumbangannya dalam pembelajaran bahasa Prancis. LingTera, 5(2), 120-132. doi:https://doi.org/10.21831/lt.v5i2.11188

doi) https://doi.org/10.21831/lt.v5i2.11188 


\section{LingTera, 5 (2), 2018 - 121}

Desi Rahmawati, Dwiyanto Djoko Pranowo

\section{PENDAHULUAN}

Manusia menggunakan bahasa sebagai alat komunikasi (Mujiyati, 2017; Nasution, 2007; Waridah, 2015; Wicaksono, 2016), yaitu untuk menyampaikan pesan dari pengirim ke penerima. Pemakaian bahasa sebagai alat komunikasi harus disesuaikan dengan situasi dan kondisi tuturan yang ada, tanpa mengabaikan kaidah penggunaan bahasa. Dalam proses komunikasi tersebut inilah akan terjadi peristiwa tutur dan tindak tutur.

Melalui tindak tutur, seseorang berusaha untuk mengungkapkan diri. Seorang penutur tidak hanya menghasilkan tuturan yang mengandung kata-kata dan struktur-struktur gramatikal saja, tetapi juga memperlihatkan tindakantindakannya. Penelitian ini mengambil tindak tutur direktif sebagai fokus penelitian karena tindak tutur direktif dianggap unik. Keunikannya terdapat dalam peristiwa memerintah atau ketika penutur menginginkan mitra tutur menuruti apa yang diinginkannya, terkadang penutur tidak menggunakan kalimat imperatif, melainkan dengan kalimat interogatif dan deklaratif. Hal itu dimaksudkan agar mitra tutur tidak tersinggung atau keberatan untuk melakukan apa yang dikehendaki oleh penutur.

Tindak tutur tidak hanya tindakan untuk berbicara, melainkan keseluruhan aspek komunikatif baik aspek pembentukannya maupun konteks tuturannya. Tindak tutur tidak hanya mengacu pada tindakan berbicara, tetapi pada keseluruhan tindak komunikatif, termasuk konteks ucapan, bukan mengenai benar salahnya suatu gramatikal, tetapi ketercapaian tujuan komunikasi (Rahman \& Gul, 2014).

Tindak tutur direktif dalam penelitian ini merupakan penelitian sosiopragmatik. Hal ini dikarenakan penggunaan bahasa yang digunakan berkaitan dengan penggunaan bahasa di dalam suatu masyarakat budaya dan dipengaruhi oleh situasi tertentu. Pada dasarnya sosiopragmatik adalah pragmatik yang terjadi di dalam konteks sosial dan konteks kultural tertentu (Leech, 1983). Oleh karena itu, prinsip-prinsip di dalam pragmatik sangat bervariatif dalam suatu situasi sosial yang berbeda dan dalam kelas sosial atau status sosial yang berbeda-beda. Berikut letak entitas sosiopragmatik di dalam kerangka pragmatik umum.

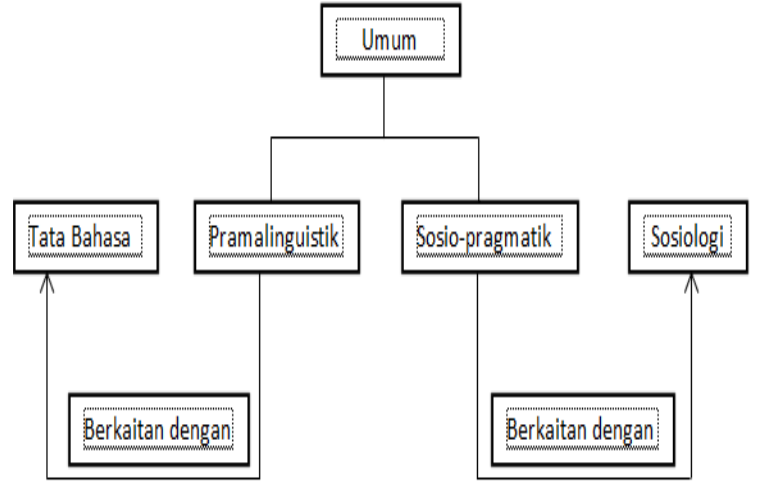

Gambar 1. Letak etnisitas sosiopragmatik

Berdasarkan Gambar 1, sosiopragmatik juga berkaitan dengan sosiologi. Di dalamnya prinsip-prinsip yang berlaku dalam sosiologi, termasuk pada sosiologi bahasa, harus diberlakukan juga dalam sosiopragmatik.

Tindak tutur direktif mengekspresikan maksud penutur sehingga ujaran atau sikap yang diekspresikannya digunakan sebagai alasan untuk bertindak oleh mitratutur. Menurut $\mathrm{Wu} \&$ Xuefeng (2010, p. 56), the point of directives is to get the hearer to do something yang berarti bahwa "poin dari direktif adalah untuk mencapai suatu hal yakni pendengar untuk melakukan sesuatu. Memperkuat pendapat tersebut Kissine (2013) mengemukakan tindak tutur direktif adalah tindak tutur yang memiliki kesamaan bahwa mereka bertujuan untuk memprovokasi tindakan dari penerima: pesanan, perintah, permintaan, permohonan dan sebagainya.

Berdasarkan strukturnya, bentuk tindak tutur direktif terdiri dari tindak tutur direktif langsung dan tidak langsung. Jika dalam suatu kalimat memiliki hubungan langsung antara struktur dengan fungsi maka dapat disebut dengan tuturan langsung. Sebaliknya jika tidak ada hubungan langsung antara struktur dengan fungsi maka tuturan tersebut dapat disebut dengan tuturan tidak langsung (Yule, 2006).

Jenis tindak tutur sendiri terdiri dari enam jenis (Harpriyanti, 2016; Ibrahim, 1993). Keenam jenis tersebut antara lain: (1) requestive berupa tuturan meminta, mengemis, memohon, menekan, mengundang, mendoa, mengajak, dan mendorong; (2) question berupa tuturan bertanya, berinkuiri, dan menginterogasi; (3) requirement berupa tuturan memerintah, menghendaki, mengomando, menuntut, mendikte, mengarahkan, menginstruksikan, mengatur, dan mensyaratkan sesuatu; (4) prohibitive berupa tuturan melarang dan membatasi; (5) permissive berupa tuturan menyetujui, membolehkan, memberi wewenang, menganugerahi, mengabulkan, membiarkan, 
mengizinkan, melepaskan, dan memperkenankan sesuatu; (6) advisory terdiri dari tuturan menasehatkan, memperingatkan, menkonseling, mengusulkan, menyarankan, dan mendorong sesuatu.

Penggunaan tindak tutur direktif terdapat dalam pemakaian bahasa, baik secara lisan maupun tulisan. Tindak tutur direktif tertulis dapat ditemukan di dalam buku ajar yakni berupa dialog-dialog. Salah satu buku ajar yang mengandung tuturan direktif adalah buku ajar bahasa Prancis Écho 1. Buku ajar bahasa Prancis Écho 1 merupakan buku ajar yang digunakan untuk menunjang pembelajaran bahasa Prancis oleh jurusan Pendidikan Bahasa Prancis Universitas Negeri Yogyakarta. Di samping itu, materi tersebut dipersiapkan untuk menghadapi ujian DELF tingkat A1.

Penelitian ini mendeskripsikan bentuk dan jenis tindak tutur direktif dalam buku ajar bahasa Prancis Écho 1 serta sumbangan dari hasil kajian tersebut terhadap pembelajaran bahasa Prancis. Hal ini dinilai penting karena dalam mempelajari buku tersebut pembelajar terkadang mengalami kesulitan. Disini sebagian besar pembelajar tidak mengetahui bentuk dan jenis dari tuturan yang ada di dalam dialog-dialog pada buku Écho 1 . Dari beberapa tindak tutur direktif yang ditemukan di dalam buku Écho 1, setelah dihitung 50,67 $\%$ diantaranya merupakan tindak tutur direktif tidak langsung sehingga pembelajar mengalami kesulitan dalam memahami makna tuturan. Hal ini dikarenakan tuturan dalam dialog di buku Écho 1 terkadang memiliki maksud dan tujuan yang tersirat bergantung pada konteksnya.

Konteks sangat berperan penting dalam memahami suatu peristiwa tutur yang dalam hal ini pada tindak tutur khususnya tindak tutur direktif seperti apa yang dikemukakan oleh (Fetzer \& Oishi, 2011) bahwa not only are speech acts situated in a context; the context itself situates the speech acts, it creates them, as it were yang berarti "Tidak hanya tindak tutur yang terletak di dalam konteks; konteks itulah yang memposisikan tindak tutur dan menciptakan tindak tutur itu sendiri." Konteks dan tindak tutur saling berkaitan satu sama lain. Selain itu, suatu tindak tutur direktif yang sama akan memiliki maksud dan tujuan yang berbeda jika konteksnya berbeda

Konteks dapat dilihat dari aspek-aspek yang melingkupi sebuah tuturan. Konteks berupa komponen-komponen tutur (Hymes, 2013; Perdi Rahayu, 2013; Suwignyo, 2012). Komponen tersebut dalam bahasa Inggris terdiri atas: (1) Setting and Scene (S) yang berkenaan dengan waktu dan tempat tuturan berlangsung, serta situasi tempat dan waktu atau situasi psikologis pembicaraan; (2) Participants (P) merujuk pada penutur dan mitra tutur yang terlibat dalam peristiwa tutur; (3) Ends (E) merujuk pada maksud dan tujuan dari suatu tuturan; (4) Acts (A) merujuk pada bentuk dan isi ujaran; (5) Key (K) merujuk pada cara, nada, dan semangat dimana pesan disampaikan; (6) Instumentalities (I) merujuk pada jalur informasi atau sarana yang digunakan untuk menyampaikan isi tuturan; (7) Norm of Interaction and Interpretation (N) merujuk pada norma-norma yang berlaku dalam masyarakat; (8) Genre (G) merujuk pada tipe atau jenis atau bentuk penyampaian pesan (Hymes, 2013).

Untuk itu, agar pembelajar lebih mudah dalam memahami dialog-dialog yang ada di dalam buku Écho 1 diperlukan sebuah strategi pembelajaran. Pengajar dapat menggunakan strategi pembelajaran model 6R. 6R adalah model pembelajaran yang dikembangkan oleh Martinez-Floor dan Uso'-Juan (Shively, 2010). Model ini berbasis pada pendekatan eksplisit yang terdiri dari enam tahap yakni researching, reflecting, receiving, reasoning, rehearsing, dan revising.

Penelitian ini dapat digunakan untuk membantu pembelajaran bahasa Prancis mengenai pembelajaran pragmatik maupun sosiopragmatik dalam pembelajaran bahasa. Selain itu dapat digunakan untuk membantu pembelajar agar lebih mudah dalam memahami dialog-dialog yang ada di dalam Écho 1 khususnya yang berkaitan dengan tuturan direktif. Dengan demikian pembelajar tidak akan mengalami kesulitan dalam memahami makna tuturan yang terkandung dalam dialog di buku ajar bahasa Prancis Écho 1 .

\section{METODE}

Penelitian ini merupakan penelitian deskripstif kualitatif, sehingga prosedur analisisnya hanya disajikan dalam bentuk deskripsi kalimat. Penelitian ini dilakukan sejak 4 Februari 2016-19 September 2016. Subjek penelitian ini yakni semua dialog yang terdapat dalam buku ajar bahasa Prancis Écho 1.

Peneliti mula-mula menyimak penggunaan bahasa yang digunakan oleh para penutur yang berupa dialog yang terdapat dalam buku ajar bahasa Prancis Écho 1 dengan membacanya secara teliti. Kemudian, peneliti mencari dan memilah-milah tuturan yang berupa tuturan direktif. Kemudian peneliti mencatatnya dan memasukkannya ke tabel data untuk dianalisis 
Data penelitian berupa tuturan yang terdapat dalam dialog di buku ajar bahasa Prancis Écho 1 yang mengandung tindak tutur direktif. Instrumen penelitian ini adalah peneliti sendiri yang bertindak sebagai perencana, pelaksana pengumpulan data, analis, penafsir data, dan pelapor hasil penelitian. Pengumpulan data dilakukan dengan metode simak dengan teknik dasar teknik sadap kemudian dilanjutkan dengan teknik SBLC (Simak Bebas Libat Cakap) dan teknik catat.

Untuk mendeskripsikan bentuk tindak tutur direktif yang terdapat dalam buku ajar bahasa Prancis Écho 1, metode analisis yang digunakan yakni metode agih dengan teknik dasar Bagi Unsur Langsung (BUL) dan teknik lanjutan baca markah dengan melihat pemarkahnya. Analisis jenis tindak tutur direktif menggunakan metode padan pragmatis dengan teknik dasar PUP (Pilah Unsur Penentu) dengan daya pilah pembeda reaksi sebagai alat penentu dan teknik lanjutan teknik HBS (Hubung Banding Menyamakan).

\section{HASIL DAN PEMBAHASAN}

\section{Bentuk tindak tutur direktif}

Bentuk tindak tutur direktif yang terdapat dalam buku ajar bahasa Prancis Écho 1 meliputi bentuk tindak tutur direktif langsung dan bentuk tindak tutur direktif tidak langsung. Hal ini dapat dilihat pada Tabel 1.

Tabel 1. Hasil Bentuk Tindak Tutur Direktif

\begin{tabular}{clcc}
\hline No. & $\begin{array}{c}\text { Bentuk tindak tutur } \\
\text { direktif }\end{array}$ & Jumlah & Presentase \\
\hline 1 & $\begin{array}{l}\text { Tindak tutur direktif } \\
\text { langsung }\end{array}$ & 73 & $49,32 \%$ \\
2 & $\begin{array}{l}\text { Tindak tutur direktif } \\
\text { tidak langsung }\end{array}$ & 75 & $50,67 \%$ \\
\hline
\end{tabular}

\section{Tindak Tutur Direktif Langsung}

Tindak tutur ini terjadi apabila suatu kalimat memiliki hubungan langsung antara struktur dan fungsinya. Salah satu tuturan yang mengandung tindak tutur direktif langsung tersebut yakni:

(1) Mélissa: Demain, il n'y a pas de cours. Qu'est-ce qu'on fait?

Mélissa: Besok, tidak ada pelajaran. Apa yang akan kita lakukan?

Tuturan tersebut terjadi pada pagi hari tanggal 13 Juli di sebuah jalan melewati sebuah gereja menuju tempat latihan pertunjukan drama (S). Mélissa (P1) sedang berbincang-bincang dengan Florent (P2). Ia bermaksud untuk mengetahui apa yang akan mereka lakukan besok karena besok tidak ada jadwal latihan (E). Kemudian ia menanyakannya ke Florent (A) dengan pelan (K). Bahasa yang digunakan adalah bahasa lisan (I). Karena mereka sudah saling kenal dan akrab, Mélissa menggunakan kata on $(\mathrm{N})$. Tuturan tersebut berbentuk dialog $(\mathrm{G})$.

Tuturan (1) merupakan bentuk tindak tutur direktif langsung. Berdasarkan konteks yang menyertainya, Mélissa menggunakan bentuk kalimat tanya sesuai dengan maksud tuturan yakni untuk menanyakan sesuatu. Ia bermaksud untuk menanyakan apa yang akan Florent lakukan besok karena besok tidak ada jadwal.

Perhatikan juga tuturan berikut.

(2) Le voisin:Vous cherchez quelqu'un?

Camille: Monsieur Patrick Dantec. Il habite bien ici?

Le voisin: La maison est à lui mais on ne le voit pas souvent.

Tetangga: Anda mencari seseorang?

Camille: Pak Patrick Dantec. Dia tinggal disini?

Tetangga: Rumah ini miliknya tapi kita tidak sering melihatnya.

Tuturan (2) terjadi di Saint-Malo, beberapa hari setelah Camille tiba di Rennes. Camille berdiri di depan rumah pamannya (S). Camille berusaha untuk menemui pamannya. Melihat ada tamu, tetangga rumah paman Camille (P1) menanyai Camille (P2) apakah ia mencari seseorang (E). Ia bertanya menggunakan kalimat tanya untuk mengetahui hal tersebut (A). Ia berbicara dengan lembut (K) kepada Camille. Bahasa yang digunakan adalah bahasa lisan (I). Karena berbicara dengan orang yang belum dikenal, tetangga pamannya menggunakan kata vous untuk memanggil Camille $(\mathrm{N})$. Kemudian tuturan tersebut berbentuk dialog $(\mathrm{G})$.

Tuturan Vous cherchez quelqu'un? Merupakan tindak tutur direktif langsung. Hal ini dikarenakan tuturan tersebut menggunakan bentuk kalimat tanya sesuai dengan maksud tuturan yakni untuk bertanya. Di dalam tuturan tersebut, tetangga paman Camille bermaksud untuk bertanya ke Camille ia sedang mencari siapa.

\section{Tindak Tutur Direktif tidak Langsung}

Tindak tutur direktif tidak langsung merupakan tindak tutur yang terjadi apabila tidak ada hubungan langsung antara struktur suatu kalimat atau tuturan dengan fungsinya. Berikut 


\section{LingTera, 5 (2), 2018 - 124}

\section{Desi Rahmawati, Dwiyanto Djoko Pranowo}

tuturan yang berbentuk tindak tutur direktif yang terdapat dalam buku ajar bahasa Prancis Écho 1 .

(3) Noémie (avec Mélissa): Lucas, c'est nous!

Lucas: Entrez.

Mélissa: On va faire un jogging. Tu viens avec nous?

Lucas: Je ne peux pas. Je travaille.

Mélissa: Qu'est-ce que tu fais?

Lucas: J'apprends le rôle de Quasimodo.

Mélissa: Toi aussi!

Noémie: Ils veulent tous le rôle de Quasimodo!

Noémie (dan Mélissa): Lucas, ini kami!

Lucas: Masuk.

Mélissa: Kita akan pergi jogging. Kamu pergi dengan kami?

Lucas: Aku tidak bisa. Aku latihan.

Mélissa: Apa yang kamu lakukan?

Lucas: Aku belajar peran Quasimodo.

Mélissa: Kamu juga!

Noémie: Semua orang menginginkan peran Quasimodo!

Tuturan (3) terjadi pada tanggal 12 Juli, pagi hari di dalam asrama mahasiswa. (S). Noémie (P1) dan Mélissa (P2) mengetuk kamar Lucas (P3). Mélissa bermaksud untuk mengajak Lucas pergi jogging (E). Ia bertanya (A) ke Lucas dengan santai (K). Bahasa yang digunakan adalah bahasa lisan (I). Karena mereka sudah saling kenal dan akrab, Mélissa menggunakan kata $t u(\mathrm{~N})$. Namun, Lucas menolaknya karena ia sedang berlatih peran menjadi Quasimodo, yakni salah satu peran dalam pertunjukan yang akan mereka lakukan. Kemudian tuturan tersebut berbentuk dialog $(\mathrm{G})$.

Tuturan $T u$ viens avec nous? merupakan bentuk tindak tutur direktif tidak langsung. Hal ini dikarenakan Mélissa menggunakan bentuk kalimat tanya yang tidak sesuai dengan maksud tuturan. Ia tidak bermaksud untuk bertanya kepada Lucas, tetapi ia bermaksud untuk mengajaknya untuk ikut jogging. Hal ini dapat dilihat dari pemarkahnya yakni On va faire un jogging yang memperjelas bahwa Mélissa mengajaknya untuk ikut jogging.

Perhatikan juga tuturan berikut.

(4) Lucas: Non, je travaille dans une pizzeria... Et toi?

Mélissa: Oh, moi, je suis professeur dans une école de danse... mais j'écris des textes de chansons.

Lucas: Je voudrais bien lire tes textes.
Mélissa: Et moi, je voudrais bien écouter tes musiques.

Lucas: Tidak, aku bekerja di sebuah rumah makan pizza... Dan kamu?

Mélissa:Oh, aku, aku seorang guru di sebuah sekolah tari... tapi aku menulis teksteks lagu.

Lucas: Aku sangat ingin melihat teks-teksmu.

Mélissa: Dan aku, aku sangat ingin mendengar musik-musikmu.

Tuturan (4) terjadi seusai Lucas dan Mélissa selesai berlatih pertunjukan. Setelah berlatih menari, Lucas dan Mélissa pergi ke kafe (S) bersama. Lucas (P1) menyanyikan sebuah lagu untuk Mélissa (P2). Mereka kemudian membicarakan pekerjaan mereka masing-masing. Karena Mélissa suka menulis lirik lagu, Lucas ingin membaca teks-teks lagu yang diciptakan Mélissa (E). Ia memohon kepada Mélissa (A) dengan nada santai (K). Bahasa yang digunakan adalah bahasa lisan (I). Tuturan menggunakan kata toi yang memperlihatkan keakraban mereka $(\mathrm{N})$. Kemudian tuturan tersebut berbentuk dialog $(\mathrm{G})$.

Tuturan Je voudrais bien lire tes textes merupakan bentuk tindak tutur direktif tidak langsung. Hal ini dikarenakan Lucas menggunakan bentuk kalimat deklaratif yang tidak sesuai dengan maksud tuturan. Dengan tuturan tersebut Lucas tidak bermaksud untuk memberitahukan sesuatu, tetapi ia bermaksud untuk memohon agar ia dapat membaca lirik lagu yang dibuat oleh Mélissa.

\section{Jenis Tindak Tutur Direktif}

Menurut jenisnya, tindak tutur direktif yang terdapat dalam buku ajar bahasa Prancis Écho 1 terdiri dari enam jenis. Keenam tindak tutur direktif tersebut meliputi requestive, question, requirement, prohibitive, permissive, dan advisory. Hal ini dapat dilihat pada Tabel 2.

Tabel 2. Hasil Jenis Tindak Tutur Direktif

\begin{tabular}{clcc}
\hline No. & $\begin{array}{c}\text { Jenis tindak tutur } \\
\text { direktif }\end{array}$ & Jumlah & Presentase \\
\hline 1. & Requestive & 30 & $20,27 \%$ \\
2. & Question & 63 & $42,56 \%$ \\
3. & Requirement & 31 & $20,94 \%$ \\
4. & Prohibitive & 2 & $1,35 \%$ \\
5. & Permissive & 8 & $5,40 \%$ \\
6. & Advisory & 14 & $9,45 \%$ \\
\hline
\end{tabular}

Requestive

Tindak tutur direktif yang berjenis requestive terdiri dari ekspresi meminta, menge- 


\section{LingTera, 5 (2), 2018 - 125}

\section{Desi Rahmawati, Dwiyanto Djoko Pranowo}

mis, memohon, menekan, mengundang, mendoa, mengajak, dan mendorong. Berikut tuturan yang merupakan tindak tutur direktif berjenis requestive.

(5) Le 8 juillet à Paris-Plage.

Florent: Je voudrais un coca, s'il vous plait. 8 Juli di Paris-Plage.

Florent: Aku ingin coca, berikan padaku.

Tuturan (5) terjadi pada pagi hari tanggal 8 Juli di sebuah pantai di Paris (S). Para pemain pertunjukan sedang berlibur ke pantai. Florent (P1) yang saat itu sedang kehausan melihat Noémie membawa minuman. Ia bermaksud untuk meminta minuman tersebut (E). Ia menggunakan kalimat deklaratif (A) dengan nada sedikit memohon (K) untuk memintanya. Bahasa yang digunakan adalah bahasa lisan (I). Karena bermaksud untuk meminta, Florent menggunakan kalimat yang sopan dengan kata voudrais $(\mathrm{N})$. Tuturan tersebut berbentuk dialog $(\mathrm{G})$.

Tuturan Je voudrais un coca, s'il vous plait digunakan Florent untuk meminta sesuatu kepada Noémie. Disini Florent bermaksud untuk meminta minuman kepada Noémie karena ia sedang kehausan. Dengan demikian, tuturan tersebut adalah tindak tutur direktif yang berjenis requestive berupa ungkapan meminta.

Perhatikan juga tuturan berikut.

(6) Claudia: On passe à table?

Fanny: Là? Maintenant? Il est six heures et demie.

Claudia: On n'a pas la télé. Alors on se couche tôt.

Jérôme: Mais on se lève tôt. Moi, tous les matins, je me lève à 6 heures.

Bertrand: Et qu'est-ce que tu fais à 6 heures?

Jérôme: Une grande balade dans la montagne. Puis je fabrique mes lampes.

Claudia: Kita bicarakan di meja?

Fanny: Disana? Sekarang? Sekarang pukul setengah tujuh.

Claudia: Kita tidak punya TV. Jadi kita tidur lebih awal.

Jérôme: Tapi kita bangun pagi lebih awal. $\mathrm{Aku}$, setiap pagi, aku bangun pukul enam.

Bertrand: Dan apa yang kamu lakukan pada pukul 6?

Jérôme: Berjalan-jalan di gunung. Lalu aku membuat lampu-lampuku.
Tuturan (6) terjadi pada malam hari di dapur milik Claudia (S). Claudia dan Fanny baru saja selesai memasak. Claudia (P1) mengajak Fanny (P2), Jérôme (P3), dan Bertrand (P4) untuk pergi ke meja dan makan malam pada saat itu (E). Ia menggunakan kalimat tanya dengan maksud untuk mengajak makan (A). Ia berbicara dengan sedikit keras (K). Bahasa yang digunakan adalah bahasa lisan (I). Karena sudah akrab, Claudia menggunakan kata on $(\mathrm{N})$. Kemudian tuturan tersebut berbentuk dialog $(\mathrm{G})$.

Tuturan On passe à table? digunakan untuk mengajak. Ketika Claudia bertanya apakah akan melewatkan sesuatu di meja, ia bermaksud untuk mengajak Fanny, Jérôme, dan Bertrand untuk makan. Dengan demikian, tuturan tersebut adalah tindak tutur direktif yang berjenis requestive berupa ungkapan untuk mengajak.

\section{Question}

Tindak tutur direktif yang berjenis question terdiri dari tuturan bertanya, berinkuiri, dan menginterogasi. Berikut tindak tutur direktif berjenis question yang terdapat dalam buku ajar bahasa Prancis Écho 1.

(7) François: Je me souviens. On pris cette photo pour l'anniversaire de Patrick. Il avait dix-neuf ans et moi vingt-quatre.

Camille: Vous êtes où?

François: Devant la maison de famille, à Saint-Malo.

François: Aku ingat. Kita mengambil foto ini untuk ulang tahun Patrick. Dia berumur Sembilan belas tahun dan aku dua puluh empat.

Camille: Kalian dimana?

François: Depan rumah keluarga, di SaintMalo.

Tuturan (7) terjadi di rumah François Dantec, dekat dengan daerah Nouméa (S). Saat bersantai dengan orang tuanya, Camille memohon ke ayahnya, François untuk memberitahu siapa sebenarnya pamannya. Kemudian François (P1) dan Camille (P2) melihat-lihat foto keluarga. Camille ingin tahu dimana mereka berfoto (E). Ia bertanya ke ayahnya dengan kalimat tanya untuk mengetahui hal tersebut (A). Ia berbicara dengan pelan dan santai (K). Bahasa yang digunakan adalah bahasa lisan (I). Untuk menghormati ayahnya, Camille menggunakan kata vous untuk menyebut ayahnya $(\mathrm{N})$. Tuturan tersebut berbentuk dialog $(\mathrm{G})$. 


\section{LingTera, 5 (2), 2018 - 126}

\section{Desi Rahmawati, Dwiyanto Djoko Pranowo}

Vous êtes où? digunakan untuk bertanya. Camille bermaksud untuk bertanya ke ayahnya. Berdasarkan konteks yang menyertainya, Camille bertanya ke François dimana mereka berfoto. Dengan demikian, tindak tutur direktif langsung tersebut berjenis question berupa ungkapan bertanya. Perhatikan juga tuturan berikut.

(8) La femme du voisin: Un sucre?

Camille: Oui, je vous remercie. Hum, il est bon, votre café... Alors, mon oncle Patrick est en Afrique...

Le voisin: Ça fait deux ans.

Camille: Et il vous donne de ses nouvelles?

Le voisin: Il m'a envoyé un message pour Noël, c'est tout. Il était à Burkina Faso.

Istri tetangga: Gula?

Camille: Ya, terima kasih. Hum, enak, kopi anda... Jadi, paman saya Patrick di Afrika.

Tetangga: Sudah dua tahun.

Camille: Dan ia memberi anda alamatnya yang baru?

Tetangga: Dia mengirimiku surat ucapan Natal, hanya itu. Dia berada di Burkina Faso.

Tuturan (8) terjadi pada siang hari di rumah tetangga Patrick Dantec, paman Camille (S). Pria tersebut mengajak Camille untuk mampir ke rumah. Istri tetangganya (P1) membuatkan Camille (P2) kopi. Camille banyak menanyakan hal-hal mengenai pamannya tersebut ke pria tersebut (P3). Ia ingin tahu apakah pamannya sekarang berada di Afrika (E). Ia menggunakan kalimat berita untuk bertanya mengenai hal tersebut (A). Ia berbicara dengan pelan dan santai (K). Bahasa yang digunakan adalah bahasa lisan (I). Karena belum kenal, Camille berbicara dengan sopan dan banyak menggunakan kata vous dan votre $(\mathrm{N})$. Tuturan tersebut berbentuk $\operatorname{dialog}(\mathrm{G})$.

Tuturan Et il vous donne de ses nouvelles? digunakan untuk bertanya. Camille bermaksud untuk bertanya kepada tetangga pamannya. Berdasarkan konteks yang menyertainya, Camille bertanya kepada tetangga pamannya tersebut apakah pamannya memberi alamatnya yang baru di Afrika. Dengan demikian, tindak tutur direktif tersebut berjenis question berupa ungkapan bertanya.

\section{Requirement}

Tindak tutur direktif yang berjenis requirement terdiri dari tuturan memerintah, menghendaki, mengomando, menuntut, mendikte, mengarahkan, menginstruksikan, mengatur, dan mensyaratkan sesuatu. Berikut tindak tutur direktif berjenis requirement yang terdapat dalam buku ajar bahasa Prancis Écho 1.

(9) Fanny: Tu as vu ces prix? $250 €$ la semaine au club Thalasso!

Bertrand: Et ce voyage au Mexique: $600 €$, $600 €$ pour un voyage au Mexique!

Fanny: Oublie le Mexique.

Bertrand: Pourquoi?

Fanny: C'est trop loin.

Fanny: Kamu lihat harganya? $250 €$ seminggu di klub Thalasso

Bertrand: Dan perjalanan ke Meksiko: $600 €$, $600 €$ untuk perjalanan ke Meksiko!

Fanny: Lupakan Meksiko.

Bertrand: Kenapa?

Fanny: Itu terlalu jauh.

Tuturan (9) terjadi di dalam sebuah ruang kerja di rumah Fanny Rochard dan Bertrand (S). Fanny bekerja di Dewan Eropa, sedangkan suaminya bekerja di sebuah bank. Mereka memiliki seorang anak bernama Caroline. Fanny (P1) dan Bertrand (P2) sedang membicarakan rencana liburan untuk mereka karena liburan sudah dekat. Ia menyuruh Bertrand untuk melupakan Meksiko (E). Ia menggunakan kalimat berita dengan maksud menyuh (A). Ia berbicara dengan keras (K) kepada suaminya. Bahasa yang digunakan adalah bahasa lisan (I). Karena mereka suami istri, Fanny menggunakan kalimat sederhana dan singkat untuk menyuruh $(\mathrm{N})$. Kemudian tuturan tersebut berbentuk dialog $(\mathrm{G})$.

Tuturan Oublie le Mexique digunakan untuk memerintah. Berdasarkan konteks yang menyertainya, tuturan tersebut digunakan oleh Fanny untuk memerintah suaminya, Bertrand. Ia bermaksud untuk memerintah suaminya agar melupakan rencana liburan mereka ke Meksiko. Dengan demikian, tindak tutur direktif pada tuturan tersebut berjenis requirement berupa ungkapan memerintah. Perhatikan juga tuturan berikut.

(10) Patrick: Alors tu reviens à Saint-Malo?

Mathilde: Oui, je vais, m'installer comme infirmière.

Patrick: Installe-toi ici.

Mathilde: C'est ta maison, Patrick. 


\section{LingTera, 5 (2), 2018 - 127}

\section{Desi Rahmawati, Dwiyanto Djoko Pranowo}

Patrick: Jadi kamu datang kembali ke SaintMalo?

Mathilde: Ya, aku akan menetap sebagai perawat.

Patrick: Tinggallah disini.

Mathilde: Ini rumahmu, Patrick.

Tuturan (10) terjadi pada malam natal tanggal 25 Desember di rumah Patrick (S). Patrick (P1) berbincang-bincang dengan Mathilde (P2) untuk menanyakan kabarnya. Patrick menghendaki Mathilde untuk tinggal di rumah itu (E). Ia menggunakan kalimat berita untuk mengatakannya (A). Ia berbicara dengan lembut (K). Bahasa yang digunakan adalah bahasa lisan (I). Karena berbicara dengan saudaranya, ia berbicara menggunakan kata toi $(\mathrm{N})$. Kemudian tuturan tersebut berbentuk dialog $(\mathrm{G})$.

Tuturan Installe-toi ici. digunakan oleh Patrick saat ia menghendaki sesuatu. Ia menghendaki Mathilde untuk tinggal di rumah Patrick yang merupakan rumah orang tua mereka karena ia sudah memutuskan tidak akan tinggal disitu lagi dan akan pindah ke Paris. Dengan demikian, tindak tutur direktif tersebut berjenis requirement berupa ungkapan menghendaki.

\section{Prohibitive}

Tindak tutur yang berjenis prohibitive terdiri dari tuturan melarang dan membatasi. Berikut tindak tutur direktif berjenis prohibitive yang terdapat dalam buku ajar bahasa Prancis Écho 1 .

(11) Claudia: On va prendre la foute de Foix.

Le gendarme: C'est interdit aussi. Il y a une manifestation des fermiers.

Bertrand: C'est toujours comme ça chez vous?

Claudia:Kita akan lewat jalan Foix.

Polisi: Itu juga dilarang. Ada demo dari para petani.

Bertrand: Itu selalu begitu di tempat kalian?

Tuturan (11) terjadi pada siang hari di jalan menuju ke pegunungan (S). tiba-tiba mobil Claudia dihentikan oleh seorang polisi. Polisi tersebut (P1) menyuruh Claudia (P2) untuk mencari jalan lain karena ada demo APPO. Claudia memutuskan akan lewat jalan Foix. Akan tetapi, polisi melarangnya karena disana ada demo para petani (E). Ia menggunakan kalimat berita untuk melarang mereka melewati jalan Foix (A). Ia berbicara dengan agak keras (K). Bahasa yang digunakan adalah bahasa lisan (I). Karena berbicara dengan masyarakat, polisi menggunkan kalimat yang formal $(\mathrm{N})$. Kemudian tuturan tersebut berbentuk dialog $(\mathrm{G})$.

Tuturan C'est interdit aussi pada tuturan (11) merupakan tindak tutur direktif yang berjenis prohibitive. Hal ini dikarenakan tuturan tersebut digunakan untuk melarang sesuatu. Berdasarkan konteks yang menyertainya, seorang polisi melarang Claudia untuk melewati jalan Foix karena disana ada demo oleh para petani dan jalan telah ditutup. Dengan demikian, tindak tutur direktif tersebut berjenis prohibitive berupa ungkapan melarang. Perhatikan juga tuturan berikut.

(12) Bertrand: Fanny, on ne peut pas aller à Arcachon!

Fanny: Et pourquoi?

Bertrand: Parcequ'ils ne prennent pas les chiens.

Fanny: C'est pas un problème. Laissons Choucroute à ters parents!

Bertrand: Fanny, kita tidak bisa pergi ke Arcachon!

Fanny: Kenapa?

Bertrand: Karena mereka tidak membawa anjing.

Fanny: Itu bukan masalah. Biarkan Choucroute bersama orangtuamu!

Tuturan (12) terjadi beberapa hari kemudian setelah Bertrand dan Fanny membicarakan rencana liburan mereka (S). Bertrand (P1) tibatiba memberitahu Fanny (P2) bahwa mereka tidak bisa pergi ke Arcachon. Kemudian Bertrand menjelaskan ke Fanny bahwa pihak agen melarang mereka membawa anjing (E). Ia menggunakan kalimat berita dengan maksud berusaha menjelaskan alasannya bahwa mereka melarang penumpang membawa anjing (A). Bertrand berbicara ke Fanny dengan pelan (K). Bahasa yang digunakan adalah bahasa lisan (I). Karena mereka suami istri, Bertrand menggunakan kalimat sederhana dan singkat $(\mathrm{N})$. Kemudian tuturan tersebut berbentuk dialog $(\mathrm{G})$.

Tuturan Parcequ'il ne prennent pas les chiens merupakan tindak tutur direktif. Tuturan tersebut berjenis prohibitive. Hal ini dikarenakan tuturan tersebut digunakan untuk melarang sesuatu. Berdasarkan konteks yang menyertainya, larangan tersebut adalah larangan dari pihak agen perjalanan yang tidak mengijinkan atau melarang untuk membawa anjing sehingga Bertrand dan Fanny tidak bisa membawa anjing mereka. Dengan demikian, tindak tutur direktif tersebut berjenis prohibitive berupa ungkapan melarang. 


\section{LingTera, 5 (2), 2018 - 128}

\section{Desi Rahmawati, Dwiyanto Djoko Pranowo}

\section{Permissive}

Tindak tutur direktif berjenis permissive terdiri dari tuturan menyetujui, membolehkan, memberi wewenang, menganugerahi, mengabulkan, membiarkan, mengijinkan, melepaskan, dan memperkenankan sesuatu. Berikut tuturan yang merupakan tindak tutur direktif berjenis permissive yang terdapat dalam buku ajar bahasa Prancis Écho 1.

\section{(13) Fanny: Bertrand, il faut partir d'ici!}

Bertrand: Je suis d'accord. Je ne peux pas continuer à ce rhytme.

Fanny: Dis à Jérôme que tu as mal au dos.

Fanny: Bertrand, kita harus pergi dari sini!

Bertrand: Aku setuju. Aku tidak bisa melanjutkan rutinitas ini.

Fanny: Katakan pada Jérôme bahwa kamu sakit punggung.

Tuturan (13) terjadi pada malam hari hari di karavan milik Claudia (S). Fanny kesal karena liburan mereka tidak sesuai dengan rencana. Fanny (P1) ingin meninggalkan rumah Claudia. Bertrand (P2) menyetujui pendapat Fanny untuk meningalkan rumah itu (E). Ia menggunakan kalimat berita untuk menyetujui pendapat Fanny (A). Ia berbicara dengan sedikit keras (K). Bahasa yang digunakan adalah bahasa lisan (I). Karena mereka suami istri, mereka berbicara menggunakan kalimat sederhana dan singkat $(\mathrm{N})$. Kemudian tuturan tersebut berbentuk dialog $(\mathrm{G})$.

Tuturan Je suis d'accord. Je ne peux pas continuer à ce rhytme. pada tuturan (13) merupakan tindak tutur direktif yang berjenis permissive. Hal ini dikarenakan tuturan tersebut digunakan dengan maksud menyetujui sesuatu. Berdasarkan konteks yang menyertainya, Bertrand bermaksud untuk menyetujui pendapat Fanny untuk segera pergi dari rumah Claudia dan Jérôme karena mereka sudah tidak tahan lagi dengan rutinitas yang dilakukan kedua teman mereka. Dengan demikian, tuturan tersebut adalah tindak tutur direktif berjenis permissive berupa ungkapan menyetujui.

Perhatikan juga tuturan berikut.

(14) Tarek: Laura, c'est dernier soir pour aller voir le film de Klapisch!

Laura: Pas ce soir, Tarek. Il faut que je prepare le réunion de demain.

Tarek: Laura, tu ne penses qu'à ton travail. Il faut qu'on sorte, qu'on aille au resto, qu'on voit des gens!

Laura: Quand on aura moins de problèmes.
Tarek: Dommage. C'est un bon film.

Laura: Vas-y seul.

Tarek: J'ai l'autorisation?

Laura: Oui, mais je t'interdis de rentrer après minuit!

Tarek: Reçu cinq sur cinq. À minuit, je te raconte le film.

Tarek: Laura, ini malam terakhir untuk melihat film Klapisch!

Laura: Tidak sore ini, Tarek. Aku harus mempersiapkan pertemuan besok.

Tarek: Laura, kamu hanya memikirkan pekerjaan. Kita perlu keluar, pegi ke rumah makan, bertemu dengan orangorang

Laura: Kalau masalah kita sedikit.

Tarek: Sayang sekali. Itu film bagus.

Laura: Pergilah sendiri.

Tarek: Aku diijinkan pergi?

Laura: Ya, tapi aku melarangmu untuk pulang lewat tengah malam!

Tarek: Setuju. Tengah malam, aku ceritakan film itu padamu.

Tuturan (14) terjadi pada hari selasa di rumah Tarek dan Laura di Grasse. (S). Setelah Laura ditolak di beberapa perusahaan, mereka memutuskan untuk pindah ke Grasse. Laura mencoba untuk membuat perusahaan parfumnya sendiri. Produk terbarunya adalah parfum untuk sebuah buku. Buku yang ada akan memiliki berbagai macam wangi parfum di setiap halamannya. Laura menyuruh Tarek untuk pergi sendiri karena ia sedang sibuk. Laura mengijinkan Tarek pergi sendiri asal ia tidak pulang tengah malam (E). Ia menggunakan kalimat perintah untuk memberi Tarek izin (A). Ia berbicara dengan agak keras (K). Bahasa yang digunakan adalah bahasa lisan (I). Karena mereka suami istri, ia berbicara menggunakan te $(\mathrm{N})$. Kemudian tuturan tersebut berbentuk dialog $(\mathrm{G})$.

Tuturan Oui, mais je t'interdis de rentrer après minuit! merupakan tindak tutur direktif yang berjenis permissive. Hal ini dikarenakan tuturan tersebut digunakan untuk mengijinkan sesuatu. Berdasarkan konteks yang menyertainya, karena Laura sedang sibuk dengan pekerjaanya dan tidak bisa menemani Tarek maka ia mengizinkan Tarek, suaminya untuk pergi menonton film Klapisch sendiri asal tidak pulang lebih dari tengah malam. Dengan demikian, tindak tutur direktif tersebut berjenis permissive berupa ungkapan mengizinkan. 


\section{Ling Tera, 5 (2), 2018 - 129}

\section{Desi Rahmawati, Dwiyanto Djoko Pranowo}

\section{Advisory}

Tindak tutur yang berjenis Advisory berupa tuturan menasehatkan, memperingatkan, menkonseling, mengusulkan, menyarankan, dan mendorong sesuatu. Berikut tindak tutur direktif berjenis advisory yang terdapat dalam buku ajar bahasa Prancis Écho 1.

(15) Tarek: Alors?

Laura: Ils ne veulent pas de moi.

Tarek: Ils sont nuls!

Laura: Tu sais, Tarek, je crois que les entretiens, $j$ 'en ai assez.

Tarek: Si tu ne cherches pas de travail, tu n'en trouveras pas.

Laura: Je n'ai plus envie de chercher. J'ai envie de créer mon entreprise.

Tarek: Jadi?

Laura: Mereka tidak menginginkanku.

Tarek: Mereka semua tidak bermutu!

Laura: Kamu tahu, Tarek, aku bosan dengan pembicaraan ini.

Tarek: Jika kamu tidak mencari pekerjaan, kamu tidak akan menemukannya.

Laura: Aku sudah tidak punya keinginan untuk mencari pekerjaan lagi. Aku ingin membuat perusahaan sendiri.

Tuturan (15) terjadi pada sabtu sore di rumah Laura dan Tarek (S). Tarek (P1) sedang bersantai meminum kopi dan makan kue. Sementara itu, Laura (P2) sedang membaca CV miliknya. Perusahaan yang ia datangi menolaknya. Lalu Tarek menasehati Laura untuk terus berusaha mencari pekerjaan (E). Ia menggunakan kalimat berita untuk menasehati istrinya (A). Ia berbicara dengan lembut ke istrinya $(\mathrm{K})$. Bahasa yang digunakan adalah bahasa lisan (I). Karena mereka suami istri, ia berbicara menggunakan kata $t u(\mathrm{~N})$. Kemudian tuturan tersebut berbentuk $\operatorname{dialog}(\mathrm{G})$.

Tuturan Si tu ne cherches pas de travail, tu n'en trouveras pas pada tuturan (15) merupakan tindak tutur direktif yang berjenis advisory. Hal ini dikarenakan tuturan tersebut digunakan dengan maksud menasehatkan sesuatu. Berdasarkan konteks yang menyertainya, tuturan tersebut digunakan oleh Tarek untuk menasehatkan sesuatu kepada Laura. Tarek menasehati Laura untuk terus berusaha mencari pekerjaan karena jika ia berputus asa dan tidak berusaha mencari pekerjaan lagi, maka sampai kapanpun ia tidak akan menemukan pekerjaan. Dengan demikian, tindak tutur direktif tersebut berjenis advisory berupa ungkapan menasehatkan.

Perhatikan juga tuturan berikut.

(16) Mathilde: Florence, tu peux me remplacer? Je ne me sens pas très bien.

Florence: Qu'est-ce que tu as?

Mathilde: Mal à la tête, des vertiges... et je suis fatigue.

Florence: Assieds-toi. Tu veux un aspirine?

Mathilde: Oui, s'il te plait.

Florence: Mathilde, tu ne peux pas continuer comme ça. Tu stresses tout le temps. Tu ne dors plus. Tu ne mange plus. Et ça, c'est depuis que Lapique est arrivée.

Mathilde: Je ne la supporte plus!

Florence: Pourquoi tu ne repars pas en Bretagne? Ta fille est grande. Tu es libre.

Mathilde: Tu vois, j'aimerais bien retourner dans la petite maison de mes parents à Saint-Malo.

Mathilde: Florence, kamu bisa menggantikanku? Aku merasa tidak enak badan.

Florence: Apa yang terjadi padamu?

Mathilde: Sakit kepala, vertigo... dan aku lelah.

Florence: Duduklah. Kamu mau aspirin?

Mathilde: Iya, boleh.

Florence: Mathilde, kamu tidak bisa seperti ini terus. Kamu stress setiap saat. Kamu tidak tidur cukup. Kamu tidak cukup makan. Dan itu, itu sejak Lapique datang.

Mathilde: Aku tidak tahan lagi!

Florence: Kenapa kamu tidak pergi ke Inggris? Anak perempuanmu sudah besar. Kamu bebas.

Mathilde: Kamu lihat, aku akan sangat suka untuk kembali ke rumah kecil milik orang tuaku di Saint-Malo.

Tuturan (16) terjadi pada siang hari di klinik Metz (S). Mathilde (P1) bekerja di klinik sebagai perawat. Ia meminta Florence (P2) untuk menggantikannya berjaga karena ia merasa tidak enak badan. Florence menyarankan ke Mathilde untuk pergi ke Inggris untuk mengunjungi rumah keluarganya (E). Ia menggunakan kalimat tanya untuk menyarankan Mathilde pergi ke Inggris (A). Ia berbicara dengan pelan ke Mathilde (K). Bahasa yang digunakan adalah bahasa lisan (I). Karena sudah akrab, ia menggunakan kata $t u(\mathrm{~N})$. Kemudian tuturan tersebut berbentuk dialog $(\mathrm{G})$. 


\section{LingTera, 5 (2), 2018 - 130}

\section{Desi Rahmawati, Dwiyanto Djoko Pranowo}

Tuturan Pourquoi tu ne repars pas en Bretagne? pada tuturan (16) merupakan tindak tutur direktif yang berjenis advisory. Hal ini dikarenakan tuturan tersebut digunakan dengan maksud untuk menyarankan sesuatu. Berdasarkan konteks yang menyertainya, Florence menyarankan Mathilde untuk pergi ke Inggris untuk menghilangkan kepenatannya, lagi pula anak perempuan Mathilde sudah besar dan ia juga tidak memiliki suami sehingga Mathilde bisa bebas bepergian kemanapun. Dengan demikian, tindak tutur direktif tersebut berjenis advisory berupa ungkapan menyarankan.

\section{Sumbangan Hasil Kajian Tindak Tutur Direktif}

Sumbangan yang dapat dilakukan dari hasil kajian terhadap tindak tutur direktif yang terdapat dalam buku ajar bahasa Prancis Écho 1 terhadap pembelajaran bahasa Prancis ini berupa strategi pembelajaran untuk mengajarkan tindak tutur direktif menggunakan model 6R yang terdiri dari researching, reflecting, receiving, reasoning, rehearsing, dan revising. Berikut keenam tahap tersebut.

\section{Researching}

Karena buku ajar bahasa Prancis Écho 1 ini diperuntukkan untuk pemula, pada tahap awal ini pengajar akan memberikan penjelasan-penjelasan terlebih dahulu. Penjelasan tersebut dapat berupa bagaimana penggunaan bahasa sebagai alat komunikasi, bagaimana cara penutur menuturkan ujarannya ketika berkomunikasi, bagaimana cara berdialog, dan kosa kata apa saja yang biasa digunakan yang bergantung pada materi yang sedang diajarkan. Setelah itu, pengajar akan menjelaskan bahwa setiap tuturan yang dibuat tersebut disertai sebuah tindakan-tindakan. Tindakan tersebut disebut dengan tindak tutur khususnya mengenai tuturan direktif. Setelah diberikan penjelasan, pembelajar akan diminta untuk mengumpulkan data-data mengenai penggunaan bahasa sebagai alat komunikasi yang berkaitan dengan tuturan direktif yang dapat mereka temukan dalam bahasa pertama mereka sesuai dengan materi yang sedang mereka pelajari.

\section{Reflecting}

Pada tahap yang kedua yakni reflecting, pengajar akan meminta pembelajar untuk menganalisis data mengenai tuturan direktif yang telah mereka peroleh dalam bahasa pertama yakni bahasa Indonesia. Pembelajar akan menganalisis data tersebut dibawah bimbingan pengajar. Pada tahap reflecting, ketika pembelajar diminta untuk menganalisis data tujuannya adalah untuk meningkatkan kesadaran para pembelajar mengenai faktor-faktor sosial yang melingkupi suatu tuturan serta situasi-situasi yang mempengaruhi tuturan yang mereka analisis. Disini pembelajar akan mengetahui bagaimana penggunaan suatu tuturan direktif dalam bahasa Indonesia juga bergantung pada faktor-faktor yang melingkupinya, seperti faktor sosial, faktor budaya, dan situasi-situasi lainnya.

\section{Receiving}

Dalam tahap ketiga yakni receiving pembelajar dapat memperoleh petunjuk mengenai penggunaan bahasa kedua. Pengajar akan memberikan penjelasan-penjelasan mengenai penggunaan bahasa Prancis. Pengetahuan-pengetahuan tersebut berupa bagaimana penggunaan bahasa Prancis untuk komunikasi sehari-hari, kosa kata apa saja yang biasa digunakan, bagaimana cara penutur asli menuturkannya, apa saja perbedaannya dengan bahasa Indonesia. Perbedaan-perbedaan inilah yang biasanya akan menjadi kendala bagi para pembelajar. Hal ini dikarenakan kaidah penggunaan bahasa Prancis dan Indonesia sangat berbeda.

Setelah memberikan penjelasan, pengajar akan diberikan beberapa contoh penggunaan tuturan direktif tersebut di dalam buku ajar bahasa Prancis Écho 1. Pembelajar dapat membandingkan penggunaan tuturan khususnya tuturan direktif dalam bahasa yang dipelajari yakni bahasa Prancis dengan bahasa pertama mereka yakni bahasa Indonesia. Dengan demikian, mereka akan mengetahui perbedaan-perbedaannya. Jika mereka sudah bisa membandingkan penggunaan tuturan dalam kedua bahasa tersebut, yakni bahasa Prancis dan bahasa Indonesia mereka akan lebih mudah untuk memahami penggunaan bahasa yang mereka pelajari.

\section{Reasoning}

Pada tahap reasoning, pengajar akan meminta pembelajar untuk menganalisis data yang mereka peroleh mengenai tuturan direktif dalam bahasa Prancis. Pembelajar akan diminta untuk menganalisis data serta mengidentifikasi data yang ada yang bersumber dari buku ajar bahasa Prancis Écho 1 sesuai dengan faktor situasional, faktor sosial, serta intensi penuturnya. Intensi yang dimaksudkan dalam hal ini adalah maksud dan tujuan dari penutur mengenai tuturan yang dibuat berdasarkan faktor-faktor yang melingkupi tuturan tersebut. Pembelajar dapat 


\section{Ling Tera, 5 (2), 2018 - 131}

\section{Desi Rahmawati, Dwiyanto Djoko Pranowo}

menganalisis data yang mereka peroleh baik secara individu maupun berkelompok.

\section{Rehearsing}

Pada tahap kelima pengajar akan meminta pembelajar untuk mempraktekkan pengetahuan yang telah mereka peroleh mengenai tindak tutur khususnya tindak tutur direktif melalui kegiatan komunikatif. Dengan kegiatan komunikatif yang dilakukan, pembelajar akan termotivasi dalam mengembangkan keterampilan berbahasanya karena kegiatan komunikatif yang akan dilakukan berkaitan dengan penggunaan bahasa dalam kehidupan sehari-hari. Kegiatan komunikatif yang akan dilakukan tidak diarahkan untuk menguasai kaidah gramatikal pembelajar, melainkan mengarah pada kemampuan dalam memproduksi tuturan khususnya tuturan direktif yang sesuai dengan konteks. Kegiatan-kegiatan tersebut dapat berupa kegiatan tanya jawab, membaca dialog, menganalisis sebuah dialog, membuat dialog, bermain peran, maupun berdiskusi.

\section{Reflecting}

Pada tahap terakhir yakni reflecting, pengajar akan memberikan umpan balik kepada pembelajar. Umpan balik yang diberikan oleh pengajar dapat berupa pemberian nilai dan komentar terhadap apa yang telah dilakukan oleh pembelajar. Pengajar dapat memberikan komentar secara tertulis pada pekerjaannya maupun secara lisan, langsung kepada pembelajar yang bersangkutan. Untuk pembelajar yang melakukan kesalahan dalam melakukan kegiatan komunikatif mengenai tindak tutur direktif, pengajar akan membantu mereka dalam mengatasinya. Dengan umpan balik yang diberikan, pembelajar akan merasa lebih dihargai dan akan meningkatkan motivasi mereka. Selain itu, pengajar akan memberikan petunjuk-petunjuk yang dapat digunakan oleh pembelajar untuk mengembangkan pengetahuannya mengenai penggunaan bahasa Prancis, khususnya mengenai tindak tutur direktif.

\section{SIMPULAN}

Berdasarkan hasil penelitian mengenai bentuk tindak tutur direktif, jenis tindak tutur direktif, dan sumbangan hasil kajian tindak tutur direktif yang terdapat dalam buku ajar bahasa Prancis Écho 1 terhadap pembelajaran bahasa Prancis, maka dapat disimpulkan bahwa:

Pertama, bentuk tindak tutur direktif yang terdapat dalam buku ajar bahasa Prancis Écho 1 yakni berupa bentuk tindak tutur direktif lang- sung dan tindak tutur direktif tidak langsung. Bentuk tindak tutur direktif yang paling dominan di dalam buku ajar bahasa Prancis Écho 1 adalah bentuk tindak tutur direktif tidak langsung. Hal ini menunjukkan bahwa peserta tutur dalam buku ajar tersebut lebih banyak menggunakan bentuk tindak tutur direktif tidak langsung sehingga mitratutur dalam tuturan-tuturan tersebut harus benar-benar memperhatikan penuturnya.

Kedua, jenis tindak tutur direktif yang terdapat dalam buku ajar bahasa Prancis Écho 1 antara lain: requestive, question, requirement, prohibitive, permissive, dan advisory. Jenis tindak tutur yang paling dominan dalam buku ajar bahasa Prancis Écho 1 adalah jenis question. Hal ini menunjukkan bahwa peserta tutur dalam buku ajar tersebut selalu ingin tahu dengan sering menanyakan sesuatu.

Ketiga, sumbangan hasil kajian tindak tutur direktif yang terdapat dalam buku ajar bahasa Prancis Écho 1 yakni penggunaan strategi pembelajaran model 6R. Model ini dapat digunakan untuk meningkatkan pembelajaran bahasa Prancis khusunya mengenai tindak tutur direktif karena tindak tutur direktif banyak ditemukan dalam buku ajar yang digunakan.

\section{DAFTAR PUSTAKA}

Fetzer, A., \& Oishi, E. (2011). Context and contexts: parts meet whole? In International Pragmatics Conference ( $\mathrm{p}$. 238). Melbourne, Vic.: John Benjamins Pub. Co.

Harpriyanti, H. (2016). Tindak tutur ilokusi dan struktur teks dalam tuturan rapat DPRD Provinsi Kalimantan Selatan periode 2009-2014. Jurnal Bahasa Sastra Dan Pembelajarannya, 6(1). Retrieved from http://jbsp.ulm.ac.id/index.php/jbsb/article /view/7

Hymes, D. (2013). Foundations in sociolinguistics: An ethnographic approach. Routledge.

Ibrahim, A. S. (1993). Kajian tindak tutur. Surabaya: Usaha Nasional.

Kissine, M. (2013). From utterances to speech acts. Cambridge University Press.

Leech, G. N. (1983). Principles of pragmatics. New York, NY.: Longman.

Mujiyati, M. (2017). Penggunaan bahasa dalam bimbingan dan konseling. JURNAL FOKUS KONSELING, 3(2), 114. https://doi.org/10.26638/jfk.426.2099 


\section{LingTera, 5 (2), 2018 - 132}

Desi Rahmawati, Dwiyanto Djoko Pranowo

Nasution, Z. (2007). Bahasa sebagai alat komunikasi politik dalam rangka mempertahankan kekuasaan. Sodality: Jurnal Sosiologi Pedesaan, 1(3). https://doi.org/10.22500/sodality.v1i3.589 7

Perdi Rahayu, S. (2013). Bentuk dan fungsi tuturan ekspresif dalam bahasa Prancis. LITERA, $11(1)$. https://doi.org/10.21831/ltr.v11i1.1152

Rahman, R., \& Gul, H. (2014). Conversation analysis: Speech acts in Ibsen's a doll's house. The Journal of Humanities and Social Sciences, 22(1), 67. Retrieved from https://www.questia.com/library/journal/1 P3-3589029531/conversation-analysisspeech-acts-in-ibsen-s-a-doll-s

Shively, R. L. (2010). From the virtual world to the real world: A model of pragmatics instruction for study abroad. Foreign Language Annals, 43(1), 105-137.

Suwignyo, H. (2012). Manifestasi tindak tutur pembelajaran among dalam wacana kelas. Jurnal Pendidikan Dan Pembelajaran (JPP), 17(2), 147-158. Retrieved from http://journal.um.ac.id/index.php/pendidik an-dan-pembelajaran/article/view/2824

Waridah, W. (2015). Penggunaan bahasa dan variasi bahasa dalam berbahasa dan berbudaya. JURNAL SIMBOLIKA: Research and Learning in Communication Study, 1(1). https://doi.org/10.31289/SIMBOLLIKA. V1I1.53

Wicaksono, L. (2016). Bahasa dalam komunikasi pembelajaran. Jurnal Pembelajaran Prospektif, 1(2). Retrieved from http://jurnal.untan.ac.id/index.php/lp3m/ar ticle/view/19211

Wu, G., \& Xuefeng, H. (2010). A corpus-based study of the INFORM group of English speech act verbs. International Forum of Teaching and Studies, 6(2), 46. Retrieved from

https://www.questia.com/library/journal/1 P3-2219913801/a-corpus-based-study-ofthe-inform-group-of-english

Yule, G. (2006). Pragmatik. Yogyakarta: Pustaka Pelajar. 